\title{
Young Corn Ear Addition Improves Some Nutrients and Lowering Glycemic Index of Chiffon Cake
}

\author{
Wan Rosli Wan Ishak*, Che Anis Jauharah Che Mohd Zin, Sathyasurya Daniel Robert \\ Nutrition Program, School of Health Sciences, Universiti Sains Malaysia, \\ Kubang Kerian, Malaysia \\ Email: rosliishak@gmail.com, anisjauharah@gmail.com, daniel@usm.my
}

Received 18 June 2014; revised 24 July 2014; accepted 6 August 2014

Copyright (C) 2014 by authors and Scientific Research Publishing Inc.

This work is licensed under the Creative Commons Attribution International License (CC BY). http://creativecommons.org/licenses/by/4.0/

(c) (i) Open Access

\begin{abstract}
The effects of partial replacement of wheat flour with young corn ear (YCE) on sensory properties and glycemic index (GI) of chiffon cake were investigated. Dried YCE was processed into powdered form and added in chiffon cake formulations to replace wheat flour partially at concentrations of 0 (control), $10 \%, 20 \%$ and $30 \%$. Protein, ash and dietary fibre contents of chiffon cake added with YCE powder were increased in line with the levels of YCE used. Even though protein content of YCE-based cakes increased in line $(13.3 \%$ to $15.7 \%)$ with the levels of YCE $(10 \%$ to $30 \%)$, but there was no significant difference compared to control. Sensory evaluation results indicate that partial replacement of wheat flour with up to $10 \%$ is satisfactory as compared to other levels of wheat flour replacement. Interestingly, addition of YCE at $10 \%$ to partially replace wheat flour resulted in reduction of postprandial blood glucose response. The GI value for chiffon cake added with YCE was 49 lower than control cake which recorded GI value at 60 . In conclusion, novel food ingredient of YCE can be incorporated in selected bakery products to enhance nutritional composition while at the same time help in reducing the GI value. Further investigation on the addition of YCE into other bakery products in relation to nutrition and glycemic response effects can also be explored.
\end{abstract}

\section{Keywords}

Young Corn Ear, Glycemic Index, Sensory Evaluation

\footnotetext{
*Corresponding author.
}

How to cite this paper: Ishak, W.R.W., Zin, C.A.J.C.M. and Robert, S.D. (2014) Young Corn Ear Addition Improves Some Nutrients and Lowering Glycemic Index of Chiffon Cake. Food and Nutrition Sciences, 5, 1545-1553. 


\section{Introduction}

Bakery-based products including cake are among renowned food items popularly consumed by many populations around the world. People often enjoy it during snacks as well as during special occasions. There are many varieties of cakes consumed by consumers. Chiffon cake is very light cake which applies foaming technique during preparation. Presently, the consumption of refined wheat flour-based products has continuously skyrocketing [1]. Generally, bakery-based products are made of refined wheat flour which is lack of natural dietary fibre. This may offer lowered health benefits compared with whole grain wheat products. A lack of dietary fibre in the meal or diet has been linked with diabetes, cardiovascular disease, cancer, constipation and other illnesses [1]. Some bakeries produced a few products that have replaced wheat flour with dietary fibre in relation to wellness and health concern by consumers [2].

Several studies have reported the potential sources of natural antioxidants on the bakery products. The use of mango dietary fibre in cookie and bread [3] and rye in bread enhances antioxidative properties and contains higher amount of antioxidant content. In addition, green tea cake was suggested to be developed as a food with more effective antioxidant properties [4]. In other study, the buckwheat was found significant in enhancement of effective antioxidant properties [5]. A few other studies also revealed that higher content of antioxidant occurred in finished bakery products [6]. Several investigations related to the use of plant-based [7]-[9] ingredients and barley [10] into processed food products to enhance functional properties and impacting glycemic responses and glycemic index (GI) were successfully done.

The GI is defined as "the incremental area under the blood glucose response curve of a 50 g carbohydrate portion of a test food expressed as percent of the response to the same amount of carbohydrate from standard food taken by the same subject” [11]. Various studies have shown that low GI diet was beneficial in reducing risks and complications of various health conditions like diabetes [12], cardiovascular diseases and cancers [13]. The GI concept is based on the physiological response (postprandial glycemia) produced by the food relative to glucose. The concept was initially coined by Jenkins et al. [14]. Low GI food is more favorable than high GI food as it produces lower and gradual glucose response. Dietary fiber improves glycemic response by reducing rate of glucose absorption in small intestine [15], hence lowering the GI value.

Presently, there is also an increase interest in GI from many public health and industrial entities. The FAO and WHO recommended that the bulk of nutrient from carbohydrate should be of low GI while having high dietary non-starch polysaccharides or dietary fibres [16]. In several countries such as Canada, South Africa, Australia, Sweden and France, the use of GI concept has been integrated in dietary guidelines given by health professional groups. In addition, there are significantly increasing number of food companies that produced low-GI processed food products.

In Malaysia the usage of locally available dietary fibre in bakery-based products is very limited. This situation is due to the unavailability of locally produced dietary fibres resources. Generally, Malaysian bakery entrepreneurs rely on dietary fibres which imported from abroad such as oat and whole grain wheat flour in their processed products. Indeed, utmost dependency on the imported raw materials confers instability of its price and may trigger food manufacturers to find an alternative resource in sustaining their commercialization activities. Up to this point, there is no such alternative vegetable dietary fibre locally available. Therefore, there is necessarily a need to explore and apply new alternative dietary fibres from vegetable which is available locally.

Young corn ears (YCE) are immature cobs of maize (Zea mays) which are containing significant amount of dietary fibre in dried form. This local agricultural by-product is harvested before or just after the silk has emerged (1 - $3 \mathrm{~cm}$ ). Its regular size is between 2 - 4 inches long and 1/3 - 2/3 inch in diameter at base [16]. It is often enjoyed as vegetable, perhaps due to its delicate flavour and crispiness. Although it is commonly used as vegetable in some Asian cuisine, YCE is now gaining its popularity in many parts of the world. In the previous study, YCE was found to be as nutritious as other vegetables such as cabbage, cauliflower, tomato, eggplant and cucumber [17]. They reported that protein and minerals in YCE were comparable with the other type of vegetables.

However, fresh YCE is highly perishable and starts to deteriorate a few days after it has been harvested. Preservation is therefore important especially during glut season to help prolong the shelf-life of YCE, so that we may benefit from its nutritional contents throughout the year. Fresh vegetables are prone to spoilage due to high moisture content [18]. Therefore, drying can be considered for preservation since it can minimize the moisture content in the vegetable, thus can prevent spoilage. Dried young corn contains significant amount of dietary fibres 
(30.4\%) which can improve certain functional properties when it is used in food products [19].

However, there is scanty information available on the application of YCE in enhancement of nutritional values in processed food products. Thus, the objective of this study was to investigate the effect of partial replacement of wheat flour with YCE on some nutritional compositions, sensory evaluation and GI of chiffon cake.

\section{Materials and Methods}

\subsection{Preparation of YCE}

Fresh young corns were purchased from Pasar Siti Khadijah, a local wet market in the central of Kota Bharu town, Kelantan, Malaysia. The young corns were processed by drying at $55^{\circ} \mathrm{C}$ in oven (Memmert GmbH \& Co. KG, Germany) and grinding (National MX-895M, Malaysia) to acquire fine powder of size approximately 125 microns (Endecotts Ltd., England). The young corn powder (YCP) was stored in Scott bottles at $4^{\circ} \mathrm{C}$ before use. YCE was used at different concentration to partially replace wheat flour in preparation of chiffon cake.

\subsection{Preparation of Chiffon Cake}

Four formulations of chiffon cake were prepared according to the formulation as described in Table 1 . To begin with, the flour was placed in a bowl together with YCE, two third of the sugar (100 g), baking powder and sodium chloride. They were uniformly mixed. The egg yolks, oil and vanilla essence were then added to the mixture. The mixture was then mixed at speed 3 using electric hand mixer (Khind HM200, Malaysia) for approximately 1 min. Meanwhile, the egg whites were beat in a separate bowl at maximum speed of 5 for about 30 sec. Cream of tartar was then put into the mixture. Mixing was continued for another 2 min to obtain foam with soft peaks. Next, the remaining one third of the sugar $(50 \mathrm{~g})$ was gradually added and mixing was kept on until foam with stiff peaks was acquired. The foam was combined with the batter by gently folding the former into the latter. The combined batter was poured into ungreased tube pan of $11 \mathrm{~cm}$ height. The cake was baked at $170^{\circ} \mathrm{C}$ in oven (Zanussi ZCG841W, England) for 30 min.

\subsection{Analyses of Nutritional Compositions}

Moisture, protein, fat, ash and total dietary fibre (TDF) contents of YCE chiffon cakes were analyzed according to AOAC [20]. Calorific values were determined by using IKA Calorimeter System, C200 Basic (IKA Werke

\section{Table 1. Formulation of chiffon cake.}

\begin{tabular}{|c|c|c|c|c|}
\hline \multirow{2}{*}{ Ingredients } & \multicolumn{4}{|c|}{ YCE content (g/100g of wheat flour) } \\
\hline & Control $(0)^{\mathrm{a}}$ & $10^{\mathrm{a}}$ & $20^{\mathrm{a}}$ & $30^{\mathrm{a}}$ \\
\hline Superfine flour & 113 & 102 & 90 & 79 \\
\hline YCP & 0 & 11 & 23 & 34 \\
\hline Corn oil & 56 & 56 & 56 & 56 \\
\hline Sucrose & 150 & 150 & 150 & 150 \\
\hline Egg white & 101 & 101 & 101 & 101 \\
\hline Egg yolk & 54 & 54 & 54 & 54 \\
\hline Skimmed milk powder & 8 & 8 & 8 & 8 \\
\hline Water & 80 & 80 & 80 & 80 \\
\hline Baking powder & 1 & 1 & 1 & 1 \\
\hline Vanilla essence & 1 & 1 & 1 & 1 \\
\hline Cream of tartar & 1 & 1 & 1 & 1 \\
\hline Sodium chloride & 1 & 1 & 1 & 1 \\
\hline
\end{tabular}

${ }^{\mathrm{a} C a k e}$ formulation was prepared with replacement of either 0, 10, 20 or $30 \mathrm{~g} / 100 \mathrm{~g}$ of superfine flour with YCE powder, respectively. 
GmbH \& Co. KG, Staufen, Germany). Total carbohydrate was calculated by difference using the formula as shown below:

$$
\% \text { carbohydrate }=100 \%-(\% \text { moisture }+\% \text { ash }+\% \text { protein }+\% \text { fat })
$$

\subsection{Sensory Evaluation}

The seven-point hedonic scales of sensory evaluation were used to determine the degree of overall likeness for the chiffon cake. Higher score indicates better quality attributes $(1=$ dislike very much and $7=$ like very much). Common sensory attributes such as colour, texture, taste and flavour of cakes were evaluated. Each attribute was independently rated by 60 panelists according to their likeness. Four samples of different chiffon cake formulations were served to every panelist coupled with water to rinse their mouth palate before testing the next sample as to minimize bias. Each sample was presented with a three-digit code. Random permutation principle was performed to determine serving order.

\subsection{Determination of Glycemic Index (GI) of Chiffon Cake Added with YCE}

Standard GI methodology described by Brouns [21] for GI determination was followed. Eleven healthy human subjects (five males and six females) were randomly selected. Inclusion criteria for selection of the subjects were: age between 18 to 75 years, BMI of 18.5 to $24.9 \mathrm{~kg} / \mathrm{m}^{2}$, non-pregnant, non-lactating, non-smoker, having no history of acute or chronic illnesses and do not undergo any surgical procedures during the past 6 months. All subjects who voluntarily agreed to participate in the study were given written informed consent. A clinical examination was done by a physician. Ethical approval for the study was acquired from the Human Research Ethics Committee of Universiti Sains Malaysia (USMKK/PPP/JEPeM (227.3) [3]).

Each subject was tested 3 times with glucose (Glucolin, Reckitt Beckinser, Malaysia) which is the reference food. Test foods containing $25 \mathrm{~g}$ available carbohydrate was tested once by every subject on seven separate sessions in a random order. Before testing, the subjects were instructed to fast overnight for about $10-14$ hours prior to attending the test session in the morning. Initially, fasting blood sample was collected before the food testing session begins. Blood was obtained by finger prick using a lancing device (Accu-Chek Multiclix, USA). Test food was then provided with a standard drinking water. The subjects were encouraged to finish the food served over 10 - 15 min. Further blood samples were then taken at 15, 30, 45, 60, 90, and 120 minutes after subject consuming the test food. Glucose concentration was analyzed using HemoCue Glucose 201 RT (Ängelholm, Sweden) that uses modified dehydrogenase method.

\subsection{Statistical Analysis}

The results were analyzed using IBM SPSS Statistics Version 19. Data were presented as mean values of three replicates \pm standard deviation (SD) which were subjected to one-way ANOVA. For comparison of means, Tukey HSD was used and significant difference was determined at $\mathrm{p}<0.05$.

\section{Results and Discussion}

The proximate composition of chiffon cakes added with different levels of young corn ear (YCE) powder was shown in Table 2. Moisture contents of cake with YCE were significantly lower than control. Initially, we found that Malaysian YCE contains 21.2\% protein, 1.3\% fat, 7.6\% ash and 38.7\% dietary fibre [19]. Due to substitution of wheat flour in chiffon cake formulation with 10 - $30 \mathrm{~g} / 100 \mathrm{~g}$ YCE, the proximate composition, especially moisture and ash were affected accordingly. In chiffon cake incorporated with YCE, moisture content ranged from 30.27 to 31.94 significantly lower $(\mathrm{p}<0.05)$ than control $(34.29 \%)$.

Low moisture content recorded in YCE-based cakes compared to control may be related to different water holding capacity of the YCE and flour. In a previous study, it was reported that moisture content of chiffon cake decrease with higher addition of gamma aminobutyric acid (GABA) tea powder due to lower water holding capacity of GABA tea powder compared to cake flour [22]. As concentration of YCE increases and wheat flour decreases, moisture contents notably reduced since wheat flour containing slightly more moisture content (9.00\%) than YCE (5.73\%). Our present results were in agreement with [1] who reported that sponge cakes added with Cheonnyuncho contained moisture ranging from 30\% to 32\%. Moisture loss during baking could 
Table 2. Nutritional compositions of chiffon cake with varied levels of YCE powder.

\begin{tabular}{ccccc}
\hline & \multicolumn{4}{c}{ YCE content (g/100g of wheat flour) } \\
\cline { 2 - 4 } & 0 & 10 & 20 & 30 \\
\hline Moisture (\%) & $34.29^{\mathrm{a}} \pm 0.05$ & $31.94^{\mathrm{b}} \pm 0.17$ & $31.92^{\mathrm{b}} \pm 0.05$ & $30.27^{\mathrm{c}} \pm 0.12$ \\
Protein (\%) & $12.47^{\mathrm{b}} \pm 1.31$ & $13.28^{\mathrm{ab}} \pm 1.47$ & $14.12^{\mathrm{ab}} \pm 1.80$ & $15.71^{\mathrm{a}} \pm 2.00$ \\
Fat (\%) & $11.73^{\mathrm{a}} \pm 0.03$ & $11.57^{\mathrm{a}} \pm 0.19$ & $11.42^{\mathrm{a}} \pm 0.02$ & $11.34^{\mathrm{a}} \pm 0.03$ \\
Ash (\%) & $0.71^{\mathrm{c}} \pm 0.02$ & $0.93^{\mathrm{b}} \pm 0.01$ & $1.19^{\mathrm{a}} \pm 0.02$ & $1.24^{\mathrm{a}} \pm 0.04$ \\
Carbohydrate (\%) & $40.80^{\mathrm{a}} \pm 2.41$ & $42.28^{\mathrm{a}} \pm 3.84$ & $41.35^{\mathrm{a}} \pm 3.89$ & $41.44^{\mathrm{a}} \pm 3.18$ \\
Total Dietary Fibre (TDF) & $0.74^{\mathrm{d}} \pm 0.07$ & $2.07^{\mathrm{c}} \pm 0.18$ & $4.11^{\mathrm{b}} \pm 0.03$ & $6.26^{\mathrm{a}} \pm 0.07$ \\
Energy (kcal/100g) & $318.65^{\mathrm{b}} \pm 3.99$ & $326.37^{\mathrm{ab}} \pm 4.64$ & $324.66^{\mathrm{ab}} \pm 3.01$ & $430.66^{\mathrm{a}} \pm 4.62$ \\
\hline
\end{tabular}

${ }^{\mathrm{a}-\mathrm{d}}$ Mean in the same row with different letter differ significantly $(\mathrm{p}<0.05)$.

have been prevented by sucrose. YCE contains 5.40\% sucrose, as reported in previous work [18]. Another possible reason why the moisture content lower in YCE-based cakes may be due to the presence of significant amount of dietary fibre in formulated products. When dietary fibre is added, water absorbtion increases thus enhancing water retention power. Addition of bamboo leaf powder into layer cake has been linked with increase in water absorption by the dietary fibre [23].

In the other nutrient, protein content of YCE cakes significantly higher than control. The protein values were increased from 12.47 (control) to 15.71\% (30\% YCE addition), and in line with the level of YCE used. Fat contents in chiffon cake added with YCE (11.34\% - 11.57\%) showed no significant variation compared to control (11.73\%). In addition, ash content was found in the increasing order of control $<10<20<30$ g/100g samples. There were significant differences in total dietary fibre (TDF) content of all YCE-based chiffon cakes. The TDF were also increased proportionally with the level of YCE incorporation (Table 2). The TDF content increased from $0.74 \%$ (control) to $6.26 \%$ (30\% YCE addition).

Higher protein content in YCE-based cakes might be explained by richer protein content (21.17\%) in YCE [19] compared to wheat flour. As declared on the nutritional label, commercial wheat flour used in the present study contains $9.00 \%$ protein. Protein difference between YCE and wheat flour is about 12.00\%. Typically, all-purpose wheat flour contains $9.50 \%$ to $11.50 \%$ protein [24]. In accordance with other study, crude proteins in biscuits were higher with incorporation of pigeon pea dehulled flour [25]. In addition, the presence of ash in food is generally reflecting total amount of minerals, the inorganic components in food. Hence, from nutritional point of view, YCE has the ability to improve mineral contents of bakery products.

Increment concentration of TDF proportionally with the levels of YCE used in cakes could be attributed to natural dietary fibre content contributed by YCE which contained 38.73 g/100g TDF [19]. Moreover, refined wheat flour is regularly used during baking. Dietary fibre is factually found in wheat bran, while refined wheat flour undergoes milling process which eliminates the bran, thus leads to loss of considerable amount of dietary fibre. Hence, this result denotes that YCE could be considered as an alternative food ingredient to increase TDF content of chiffon cakes. Our present study demonstrated that the TDF content of chiffon cake can be increased by partially replace wheat flour with YCE. A group of researcher [26] concluded that muffins incorporated with apple skin powder were higher in dietary fibre and total antioxidant capacities. Jenkins et al. [27] suggested that a very potent and palatable soluble fibre, known as viscous fibre blend, when added to starchy snack, particularly biscuit, was able to reduce the glycemic response to a similar extent in both healthy individuals and patients with diabetes mellitus. The implication of this is that consumers may have more healthy choices on the bakery shelves. Figure 1 shows images of chiffon cake prepared with different levels of YCP.

Sensory measurement to evaluate preference and product acceptability using hedonic scale technique is a unique score providing both valid and reliable results. When judged by 60 untrained panelists, statistically significant differences were found in the colour, flavour, texture, taste and overall acceptability scores among the 0 g, $10 \mathrm{~g}, 20 \mathrm{~g}$ and $30 \mathrm{~g} / 100 \mathrm{~g}$ samples (Table 3). Overall acceptance score of chiffon cake formulations at $10 \%$ addition YCE to replace wheat flour recorded the highest scores for taste, flavor and overall acceptability (5.45, 


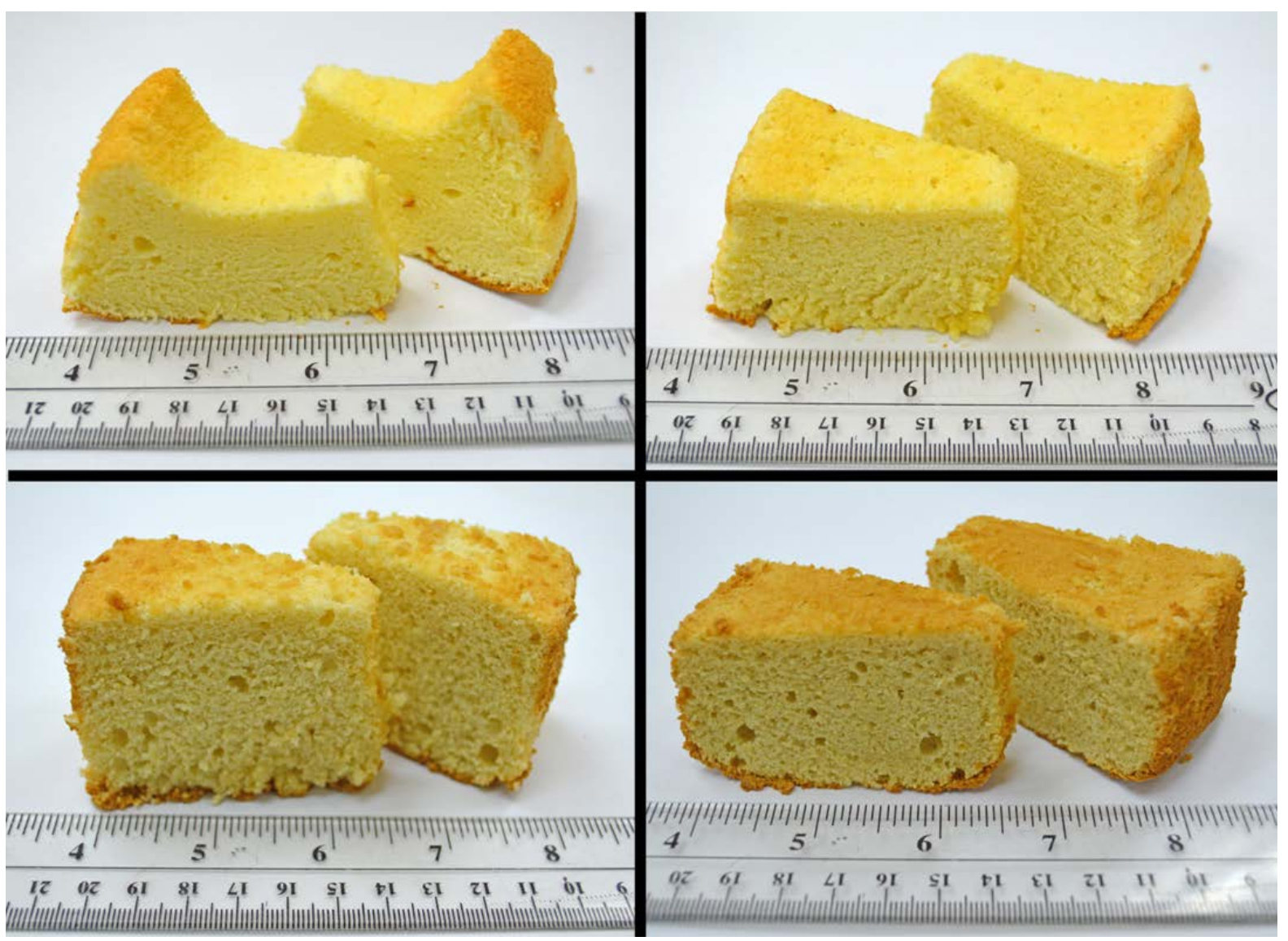

Figure 1. Chiffon cake prepared with $0 \%$ (left upper), 5\% (right upper), 10\% (left lower) and 15\% (right lower) of YCP.

Table 3. Sensory characteristics of chiffon cake with varied levels of YCE powder.

\begin{tabular}{ccccc} 
& \multicolumn{4}{c}{ YCE content $(\mathrm{g} / 100 \mathrm{~g}$ of wheat flour $)$} \\
\cline { 2 - 4 } & 0 & 10 & 20 & 30 \\
\hline Colour & $5.68^{\mathrm{a}} \pm 1.40$ & $5.52^{\mathrm{a}} \pm 1.07$ & $4.77^{\mathrm{b}} \pm 1.11$ & $4.00^{\mathrm{c}} \pm 1.57$ \\
Texture & $5.60^{\mathrm{a}} \pm 1.37$ & $5.37^{\mathrm{a}} \pm 1.28$ & $5.12^{\mathrm{a}} \pm 0.99$ & $4.37^{\mathrm{b}} \pm 1.46$ \\
Taste & $5.43^{\mathrm{a}} \pm 1.31$ & $5.45^{\mathrm{a}} \pm 1.16$ & $5.18^{\mathrm{a}} \pm 1.16$ & $4.55^{\mathrm{b}} \pm 1.37$ \\
Flavour & $5.22^{\mathrm{ab}} \pm 1.37$ & $5.57^{\mathrm{a}} \pm 1.11$ & $5.25^{\mathrm{ab}} \pm 1.11$ & $4.67^{\mathrm{b}} \pm 1.35$ \\
Overall acceptability & $5.43^{\mathrm{a}} \pm 1.14$ & $5.55^{\mathrm{a}} \pm 1.03$ & $5.28^{\mathrm{a}} \pm 1.08$ & $4.68^{\mathrm{b}} \pm 1.17$ \\
\hline
\end{tabular}

${ }^{\mathrm{a}-\mathrm{b}}$ Mean in the same row with different letter differ significantly $(\mathrm{p}<0.05)$.

5.57 and 5.55, respectively) among all formulations. However these values were not statistically difference ( $>$ 0.05 ) compared to cakes added with 20\% YCE and control (0\% YCE). Both cakes prepared with $0 \%$ YCE (control) and 10\% YCE were not significantly different $(\mathrm{p}>0.05)$ in colour and texture attributes. Briefly, mean score for each attribute was $5 / 7$, indicating that the addition of $10 \mathrm{~g} / 100 \mathrm{~g}$ is moderately acceptable. On the contrary, 30\% cake sample score significantly lower than other formulations for most attributes.

Product liking and preference were measured using unique scale as to provide reliable and valid results. The sensory evaluation results indicate that partial replacement of wheat flour with up to $10 \%$ is satisfactory. This finding was in agreement with other study, where the researchers found that sensory acceptance of young corn products, i.e. several Indian snack foods and savouries, sweet products and pickles were higher than control [28]. Concurrently, other study on muffin blended with corn by-products had also reported that $10 \%$ blending level 
was highly acceptable, yet significant decrease in score was noted for higher percentage of blending level [29].

In GI determination, subjects consist of 5 men and 6 women aged (mean \pm SD) $28.7 \pm 5.2$ years old with BMI $22.8 \pm 1.8$ (range 19.5 - 24.9), fasting blood glucose $5.2 \pm 0.5 \mathrm{mmol} / \mathrm{l}$ (range 4.6 - 6.0) and blood pressures 118 $\pm 13 / 74 \pm 9 \mathrm{mmHg}$ volunteered to participate in this study. The test meals were well tolerated and the seven test sessions were successfully completed by all subjects. The correlation of variation of the AUC of three times repeated glucose tests was $19.0 \% \pm 9.6 \%$. Test foods selected for the GI investigation were chiffon cake formulated with either $0 \%$ or $10 \%$ of YCE. Chiffon cake added with $10 \%$ YCE was chosen for GI determination because it received the highest sensory scores as perceived by panelists (Table 3). Palatability is one of the vital components in ensuring the selection of food by consumers.

In addition, there was no statistically significant difference between the area under curve (AUC) of control and 10\% YCE cakes $(\mathrm{p}=0.992)$. However, the AUC after control cakes and 10\% YCE cakes were significantly lower than the glucose $(\mathrm{p}<0.05)$. GI value of control cake did not differ significantly from glucose $(\mathrm{p}=0.092)$. Meanwhile, 10\% YCE cake had GI value (Figure 2) which was statistically significant from glucose ( $\mathrm{p}=0.024)$. There was a positive correlation between the AUC of test foods and their respective GI values $(r=0.736, p<$ $0.001)$.

The result showed that mean glucose responses of chiffon cake added with 10\% YCE were lower than the control cake (Table 4). The GI value for chiffon cake added with YCE was 49 lower than control cake which recorded GI value at 60. Based on GI classification, control cake had an intermediate GI (56 to 70) while 10\% YCP cake had a low GI value $(\leq 55)$.

There are various factors of foods that affect GI include gross and cellular structures, nature of starch, type of sugar, organic acid and dietary fibre contents [30]. In the present study we purported that the dietary fibre content might have influenced the glycemic responses of the chiffon cake. Addition of dietary fibre to carbohydrate-based foods can affect the GI of the food although the dietary fibre itself does not have a GI value [27]. The presence of dietary fibre can delay gastric emptying and slows digestion and absorption rate of available carbohydrates. In addition, YCE seemed to be more effective in reducing the postprandial glycemic response

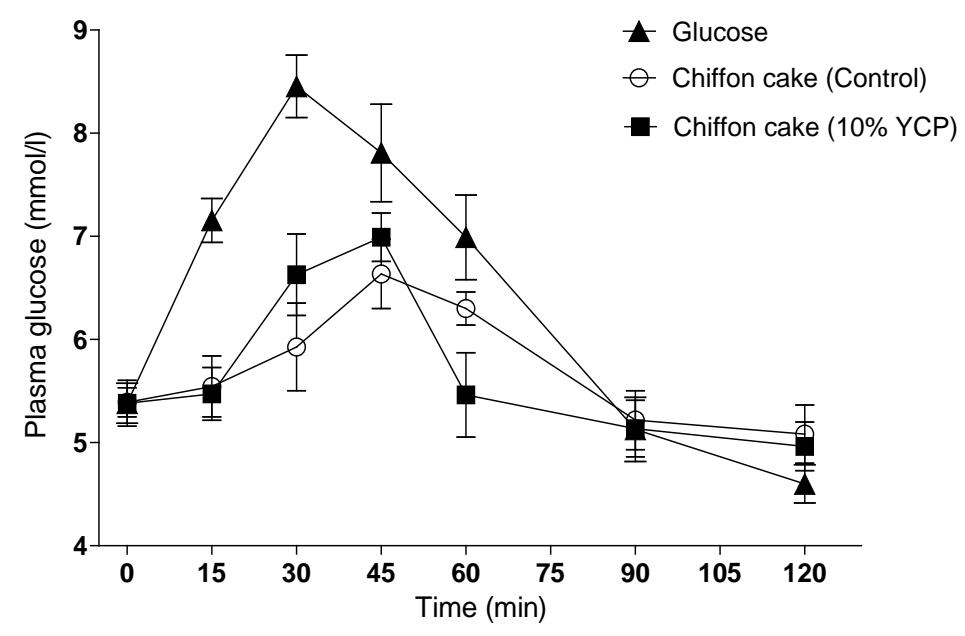

Figure 2. Mean plasma glucose response of 11 subjects to chiffon cakes with and without YCE addition.

Table 4. Glucose responses and GI of chiffon cakes added with YCE powder.

\begin{tabular}{ccc}
\hline Test foods & AUC mmol $\times$ min/l & GI \\
\hline Control chiffon cake & $72^{\mathrm{b}} \pm 15$ & $60^{\mathrm{b}} \pm 6$ \\
$10 \%$ YCE chiffon cake & $69^{\mathrm{b}} \pm 15$ & $49^{\mathrm{c}} \pm 4$ \\
Glucose & $154^{\mathrm{a}} \pm 17$ & $100^{\mathrm{a}}$ \\
\hline
\end{tabular}

${ }^{\mathrm{a}-\mathrm{c}}$ Mean in the same column with different letter differ significantly $(\mathrm{p}<0.05)$. 
when added to the chiffon cakes. In accordance with other studies, we found that protein had inverse relationship with GI. Protein also well helps reduce postprandial glycemia by promoting secretion of insulin and delaying gastric emptying [31].

\section{Conclusion}

The proximate compositions, especially moisture and ash contents of chiffon cake added with YCE are affected. Both protein and dietary fibres contents of chiffon cakes added with YCE at higher percentage were significantly higher than control. Sensory evaluation results indicate that partial replacement of wheat flour with up to $10 \%$ is satisfactory as compared to other levels of wheat flour replacement. Addition of YCE at $10 \%$ to partially replace wheat flour resulted in reduction of postprandial blood glucose response, and thereby enhanced the functional quality of the product. In conclusion, this study shows that novel food ingredients like YCE can be incorporated in selected bakery products to enhance nutritional composition while at the same time help in reducing the GI value. The ability of YCE in improving nutrition and glycemic responses in other food products can be investigated further.

\section{Acknowledgements}

The study was funded by Universiti Sains Malaysia (1001/PPSK/813057). Special thanks to all staffs and students who participate in sensory evaluation.

\section{References}

[1] Kim, J.H., Lee, H.J., Lee, H.N., Lim, E.J. and Suh, H.J. (2001) Physical and Sensory Characteristics of Fibre-Enriched Sponge Cakes Made with Opuntia humifusa. LWT_Food Science and Technology, 47, 478-484.

[2] Huh, K. (2006) Woorimil (Korean Wheat) Bread without Antibiotics. http://newsnaver.com/news/

[3] Vergara-Valencia, N., Granados-Perez, E., Agama-Acevedo, E., Tovar, J., Ruales, J. and Bello-Perez, L.A. (2007) Fiber Concentrate from Mango Fruit: Characteristics, Associated Antioxidant Capacity and Application as a Bakery Product Ingredient. LWT-Food Science and Technology, 40, 722-729.

[4] Lu, T.-M., Lee, C.-C., Maud, J.-L. and Lin, S.-D. (2012) Quality and Antioxidant Property of Green Tea Sponge Cake. Food Chemistry, 119, 1090-1095. http://dx.doi.org/10.1016/j.foodchem.2009.08.015

[5] Lin, L.-Y., Liu, H.-M., Yu, Y.-W., Lin, S.-D. and Mau, J.-J. (2009) Quality and Antioxidant Property of Buckwheat Enhanced Wheat Bread. Food Chemistry, 112, 987-991. http://dx.doi.org/10.1016/j.foodchem.2008.07.022

[6] Michalska, A., Ceglinska, A., Amarowicz, R., Piskula, M.K., Szawara-Nowak, D. and Zielinski, H. (2007) Antioxidant Contents and Antioxidative Properties of Traditional Rye Breads. Journal of Agricultural and Food Chemistry, 55, 734-740. http://dx.doi.org/10.1021/jf062425w

[7] Reyes-Pérez, F., Salazar-García, M.G., Romero-Baranzini, A.L., Islas-Rubio, A.R. and Ramírez-Wong, B. (2013) Estimated Glycemic Index and Dietary Fiber Content of Cookies Elaborated with Extruded Wheat Bran. Plant Foods for Human Nutrition, 68, 52-56. http://dx.doi.org/10.1007/s11130-013-0338-0

[8] Kanellos, P.T., Kaliora, A.C., Liaskos, C., Tentolouris, N.K., Perrea, D. and Karathanos, V.T. (2013) A Study of Glycemic Response to Corinthian Raisins in Healthy Subjects and in Type 2 Diabetes Mellitus Patients. Plant Foods for Human Nutrition, 68, 145-148. http://dx.doi.org/10.1007/s11130-013-0348-y

[9] Menezes, E.W., Dan, M.C., Candenette, G.H., Goni, I., Bello-Perez, L.A. and Lajolo, F.M. (2010) In Vitro Colonic Fermentation and Glycemic Response of Different Kinds of Unripe Banana Flour. Plant Foods Human Nutrition, 65, 379-385. http://dx.doi.org/10.1007/s11130-010-0190-4

[10] Chillo, S., Ranawana, D.V., Praat, M. and Henry, C.J.K. (2011) Glycemic Response and Glycemic Index of Semolina Spaghetti Enriched with Barley $\beta$-Glucan. Nutrition, 27, 653-658. http://dx.doi.org/10.1016/j.nut.2010.07.003

[11] FAO/WHO (1997) Carbohydrate in Human Nutrition Report on a Joint FAO/WHO Expert Consultation. FAO and Nutrition Paper No. 66, Rome, 14-18 April 1997.

[12] Salmerón, J., Ascherio, A., Rimm, E.B., Colditz, G.A., Spiegelman, D., Jenkins, D.J., Stampfer, M.J., Wing, A.L. and Willett, W.C. (1997) Dietary Fiber, Glycemic Load, and Risk of Niddm in Men. Diabetes Care, 20, 545-550. http://dx.doi.org/10.2337/diacare.20.4.545

[13] Barclay, A.W., Petocz, P., McMillan-Price, J., Flood, V.M., Prvan, T., Mitchell, P. and Brand-Miller, J.C. (2008) Glycemic Index, Glycemic Load, and Chronic Disease Risk: A Meta-Analysis of Observational Studies. The American Journal of Clinical Nutrition, 87, 627-637. 
[14] Jenkins, D.J., Wolever, T.M., Taylor, R.H., Barker, H., Fielden, H., Baldwin, J.M., Bowling, A.C., Newman, H.C., Jenkins, A.L. and Goff, D.V. (1981) Glycemic Index of Foods: A Physiological Basis for Carbohydrate Exchange. The American Journal of Clinical Nutrition, 34, 362-366.

[15] Cherbut, C., Varannes, S.B.D., Schnee, M., Martine, R., Galmiche, J. and Delort-Laval, J. (1994) Involvement of Small Intestinal Motility in Blood Glucose Response to Dietary Fibre in Man. British Journal of Nutrition, 71, 615-685. http://dx.doi.org/10.1079/BJN19940175

[16] Chutkaew, C. and Paroda, R.S. (1994) Baby Corn Production in Thailand: A Success Story. Asia-Pacific Association of Agricultural Research Innovation Publication, Bangkok.

[17] Hooda, S. and Kawatra, A. (2013) Nutritional Evaluation of Baby Corn (Zea mays). Nutrition and Food Science, 43, 68-73. http://dx.doi.org/10.1108/00346651311295932

[18] Gore, H.C. and Mangels, C.E. (1931) The Relation of Moisture Content to the Deterioration of Raw-Dried Vegetables upon Common Storage. Journal of Industrial and Engineering Chemistry, 13, 6-8.

[19] Rosli, W.I.W. and Anis, J.C. (2012) The Potential of Zea mays Ears and It Extracts as an Alternative Food Nutritive Ingredients. APCBEE Procedia, 2, 141-147. http://dx.doi.org/10.1016/j.apcbee.2012.06.026

[20] AOAC (2000) Official Method of Analysis of the Association of Official Analytical Chemists. 15th Edition, AOAC International, Arlington.

[21] Brouns, F., Bjorck, I., Frayn, K.N., Gibbs, A.L., Lang, V., Slama, G. and Wolever, M.S. (2005) Glycaemic Index Methodology. Nutrition Research Reviews, 18, 145-171. http://dx.doi.org/10.1079/NRR2005100

[22] Lee, C.C. and Lin, S.D. (2008) Effect of Gaba Tea on Quality Characteristics of Chiffon Cake. Cereal Chemistry, 85, 31-38. http://dx.doi.org/10.1094/CCHEM-85-1-0031

[23] Song, Y.S. and Hwang, S.Y. (2007) A Study on the Characteristics of Yellow Layer Cake Made with Bamboo Leaf Powder. Korean Journal of Food and Nutrition, 20, 164-172.

[24] Figoni, P.I. (2011) How Baking Works: Exploring the Fundamentals of Baking Science. 3rd Edition, John Wiley and Sons, Inc., Hoboken.

[25] Tiwari, B.K., Brennan, C.S., Jaganmohan, R., Surabi, A. and Alagusundaram, K. (2011) Utilisation of Pigeon Pea (Cajanus cajan L) Byproducts in Biscuit Manufacture. LWT, Food Science and Technology, 44, 1533-1537.

[26] Rupasinghe, H.P.V. (2008) Effect of Baking on Dietary Fibre and Phenolics of Muffins Incorporated with Apple Skin Powder. Food Chemistry, 107, 1217-1224.

[27] Jenkins, A.L., Jenkins, D.L., Wolever, T.M., Rogovik, A.L., Jovanovski, E., Božikov, V., Rahelić, D. and Vuksan, V. (2008) Comparable Postprandial Glucose Reductions with Viscous Fiber Blend Enriched Biscuits in Healthy Subjects and Patients with Diabetes Mellitus: Acute Randomized Controlled Clinical Trial. Croatian Medical Journal, 49, 772782. http://dx.doi.org/10.3325/cmj.2008.49.722

[28] Anitha, G. and Rajyalakshmi, P. (2005) Baby Corn (Zea mays L.): Physico-Chemical Characteristics and Use in Product Development. Journal of Food Science and Technology, 42, 234-238.

[29] Sharma, S., Gupta, J., Nagi, H. and Kumar, R. (2012) Effect of Incorporation of Corn Byproducts on Quality of Baked and Extruded Products from Wheat Flour and Semolina. Journal of Food Science and Technology, 49, 580-586.

[30] Arvidsson-Lenner, R., Axelsen, M., Bryngelsson, S., Haapa, E., Jarvi, A., Karlstrom, B., Raben, A., Sohlstrom, A., Thorsdottir, I. and Vessby, B. (2004) Glycaemic Index: Relevance for Health, Dietary Recommendations and Food Labelling. Scandinavian Journal of Nutrition, 48, 84-94.

[31] Hätönen, K.A., Virtamo, J., Eriksson, J.G., Sinkko, H.K., Sundvall, J.E. and Valsta, L.M. (2011) Protein and Fat Modify the Glycaemic and Insulinaemic Responses to a Mashed Potato-Based Meal. British Journal of Nutrition, 106, 248253. http://dx.doi.org/10.1017/S0007114511000080 
Scientific Research Publishing (SCIRP) is one of the largest Open Access journal publishers. It is currently publishing more than 200 open access, online, peer-reviewed journals covering a wide range of academic disciplines. SCIRP serves the worldwide academic communities and contributes to the progress and application of science with its publication.

Other selected journals from SCIRP are listed as below. Submit your manuscript to us via either submit@scirp.org or Online Submission Portal.
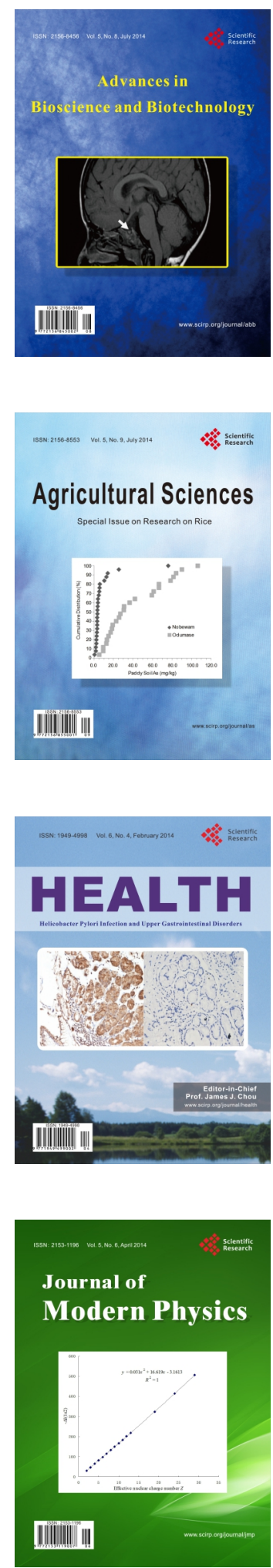
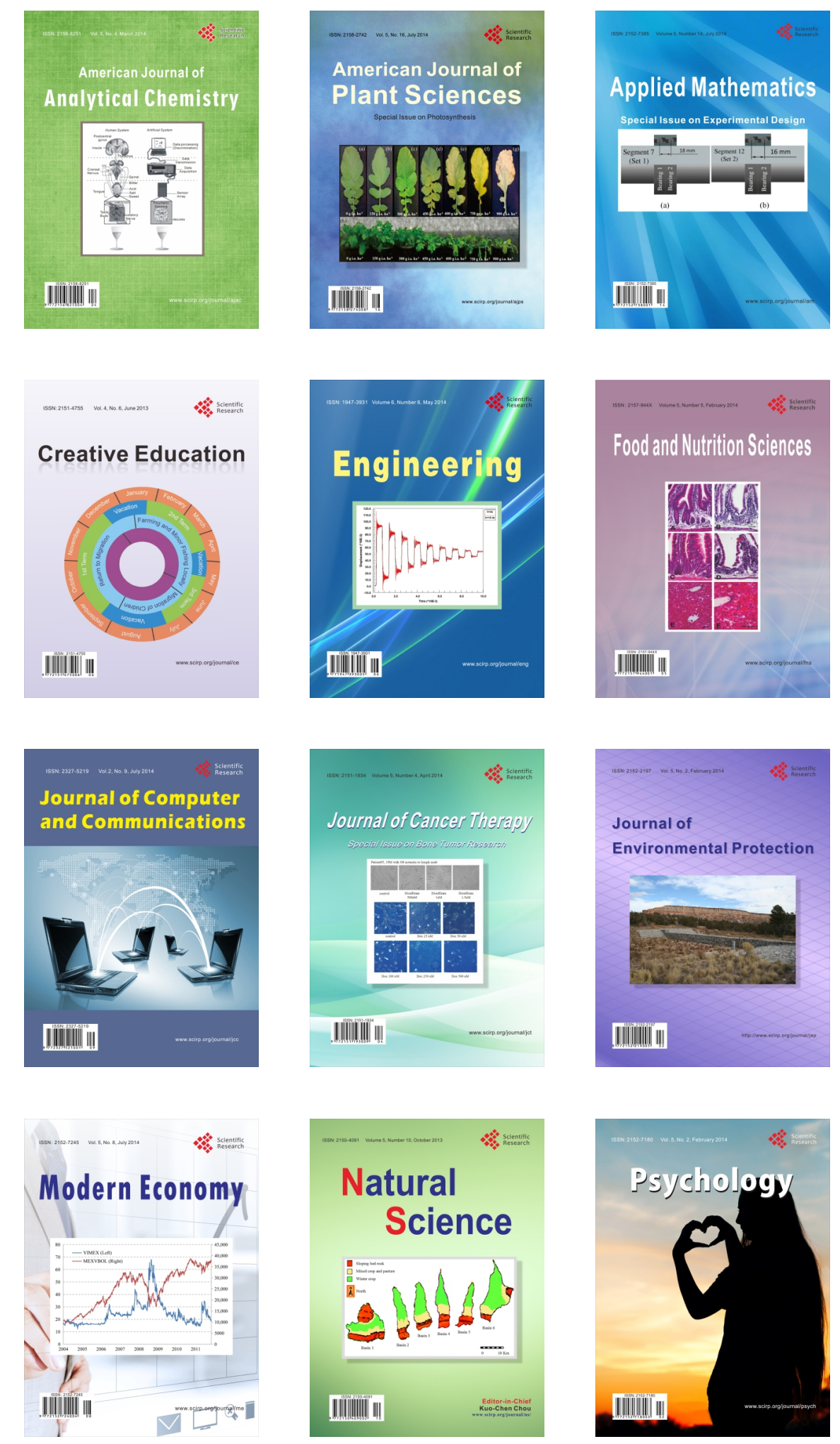